\title{
Make Public: Performing public housing in Ernő Goldfinger's Balfron Tower
}

David Roberts

To 'make public' expresses three aims that have driven my doctoral research into the past and future of east London housing estates undergoing regeneration; materially - to protect public housing provision at a time when austerity measures are dismantling it in ideal and form; procedurally - to make visible problematic processes of urban change that are increasingly hidden from public view; and methodologically - to make public my act of research through intimate and sustained collaboration with residents on site. This research document focuses on Balfron Tower, a high-rise of 146 flats and maisonettes arranged on 26 storeys built in 1965-7, the first phase of émigré architect Ernő Goldfinger's work on the Greater London Council's (GLC) Brownfield Estate in Poplar.

In December 2015, the London Borough of Tower Hamlets approved plans to refurbish and privatise Balfron Tower. In this paper, I describe my collaborative work with the tower's current and former residents in the preceding three years during which we campaigned for Balfron to remain a beacon for social housing. I structure the paper on the three phases this work followed; analysis of cultural, academic and archival material which foregrounds both the persistent accusations of failure that have afflicted the tower and the egalitarian principles integral to its vision and function as social housing; engagement with residents re-enacting Goldfinger's own methods of gathering empirical evidence in 1968, and; activism drawing on this material and evidence to contribute to informed public debate and planning decisions.

Through this paper, I illustrate how Balfron's history was mobilised to commodify the tower on the one hand, and to interrogate and object to this process on the other. In doing so, I advance an argument that the practice and guidance of heritage of post-war housing estates must not only pay tribute to the egalitarian principles at their foundations, it must enact them. 
Throughout the shifting course of opinion, both popular and expert, certain judgments of Balfron Tower have been accepted uncritically - correlating its architecture of dramatic proportions with a way of life as stark and severe, ill-suited to the needs of families, and at a high density in which socialisation is difficult - prompting one politician to declare it 'the benchmark of post-war architectural failure' and a regeneration manager to recommend 'this and all its ilk should be demolished and consigned to the bin marked "failed experiment"'. ${ }^{1}$

In a paper to the Courtauld Institute twenty years ago, historian Adrian Forty reflected on some of the reasons why the architecture of the post-war period absorbs our interest, and some of the things that stand in the way of our understanding. ${ }^{2}$ He noted the first, and most awkward, fact faced by the historian is that it is widely considered a failure. This label of failure, he observed, is reserved almost exclusively for works built by the state, and, most commonly, in reference to social housing schemes. Forty suggested the mistake historians have made is to look in the wrong place for the causes of failure. With very detailed historical attention they have vindicated the architects or buildings themselves by stressing their aesthetic qualities and honourable intentions, though, in doing so, they often overlook social issues or propose causal explanations for their failure on technical or cultural grounds. Instead, Forty offered, it would be better to 'examine the minds of those who judge these works'. ${ }^{3}$ We should not, he said, be troubled by whether or not they actually were a failure but that they have been perceived to be. ${ }^{4}$

I wish to take on Forty's thorny epistemological and methodological challenge of perception in relation to Balfron Tower. I speculate that most people have not taken the opportunity to visit and gain direct experience of the tower, so how else might they have arrived at the damning conclusion of failure? To answer this, I briefly consider the body of cultural material that broadcasts a certain perception of the tower to the public.

The most famous representations of Balfron Tower are in feature films which go beyond the typical kitchen sink dramas set in housing estates to fictive dystopian wastelands. In Danny Boyle's harrowing sci-fi horror 28 Days Later, a virus has spread to humans turning them into 'the infected', frothing zombies that scale the tower in vicious bands. ${ }^{5}$ In Elliott Lester's crime thriller Blitz, Balfron stars as the home of a strutting psychotic serial killer who murders members of the police force. ${ }^{6}$ Paul Anderson's Shopping is set in the tower block and follows its gang of feral teenage residents who indulge in joyriding and ram-raiding. ${ }^{7}$ These films, and countless others, use Balfron as a backdrop for invariably frightening incidents in which the tower appears from acute angles, its warm aggregate stained under filters. They exploit Balfron's height and style as inherently unsafe and violent, and embellish its neglect, both material and social, by dressing the tower in graffiti and abandoned cars. This is reinforced in the accompanying dialogue: 'Look at this place, how do people live in this filth? ... This whole estate's a disgrace'. ${ }^{8}$ Ben Campkin has characterised this powerful imaginary of decline that has encircled post-war estates and distorted our understanding, 'taking them into a representational realm of abstract generalisation'. ${ }^{9}$ Campkin explores this characterisation further here in Chapter 9.

This is a reading echoed in newspaper reports. In 2014-15, the Mirror described the building as 'attracting muggers, drug gangs and junkies and rumoured to once be the local council's go-to solution for problem tenants'; ${ }^{10}$ Time Out portrayed 'junkies in the stairwells, domestic violence, drug deals and constant low-level crime'; ${ }^{11}$ and the Daily Mail summarised Balfron as 'known for violence, crime and poverty. ${ }^{12}$ This is taken even further by the Sunday Times, which identified it as 'the ugliest building in London' and by LBC radio as the 'worst eyesore in London', and upgraded still by the Mirror and Evening Standard who anointed it 'Britain's ugliest building'. ${ }^{13}$ We must question 
where the evidence for these claims lies. One possible explanation is simply the style it has come to symbolise - its categorisation as a 'leading example of so-called Brutalist architecture' ${ }^{14}$ In 2000, Simon Jenkins in the Times wrote:

the 24-storey Balfron Tower by the brutalist architect Ernő Goldfinger ... gives Poplar a final mugging. Its footings are a no-go area for humanity. Trash, chicken-wire and graffiti abound. The tower is without charm or visual diversion. It makes Wormwood Scrubs seem like the Petit Trianon. Poverty is not Poplar's curse. The curse is architecture. ${ }^{15}$

The term 'Brutalism' was coined by architects Alison and Peter Smithson and theorised by critic Reyner Banham after the French word 'brut', referring to the uncompromising use of raw concrete that figured boldly in abstract geometries of late Modernist buildings. ${ }^{16}$ Goldfinger's use of bushhammered concrete and the dramatic style of his designs mean that they are often categorised as Brutalist yet, like many of his contemporaries, he never used, and actively disliked the term. In cultural and media representations like Jenkins', Brutalism is most commonly used as an intentional conflation of an architectural style and the brutal behaviour that takes place within it. Ike ljeh in Building wrote:

The sixties tower block is also a building type now widely despised and perhaps the only reliable way to deepen the antipathy in which it is generally held is to garnish it with the toxic epithets 'concrete' and 'brutalist'. Heroically, Balfron House ticks all said boxes ... many of [its] features embody the widely discredited ideologies that continue to stigmatise sixties public housing to this day including inhuman character, pugnacious form, multiple raised deck access and appalling thermal performance. ${ }^{17}$

Alongside the aesthetic condemnation, ljeh's insinuation of structural failings is repeated by many other commentators; The Mirror describes it as 'decayed', The Evening Standard as 'asbestos-ridden' and The Guardian as 'decaying' and a 'crumbling obelisk'. ${ }^{18}$ These representations amass to create an image of violent intent and material decay, both physical and, by inference, social. Finally, the Architects' Journal describes the tower as 'an impenetrable fortress' in which flats are 'clad with penitentiary steel bars', and The Mirror depicts Balfron as 'the kind of place where people rush past with their heads bowed, terrified of making eye contact with their unknown neighbours' ${ }^{19}$ As performance theorists Charlotte Bell and Katie Beswick have noted elsewhere, it makes us, as viewers, speculate in the popular belief that there is 'a correlative relationship between the council estate environment and "pathological" behaviour of estate residents' - in this case an architectural determinism so extreme that a brutal building might even breed brutal murderers. ${ }^{20}$

These images of Balfron Tower have a much less firm place in popular culture than those of its creator. By accident of a bizarre set of circumstances that brought his exotic name to the attention of James Bond author lan Fleming, Goldfinger is fated to exist as much in fiction as in flesh and blood. ${ }^{21}$ Indeed, almost every article repeats the trite contention that he provided the inspiration for Fleming's villain. As the Architects' Journal has noted, 'a large part of Goldfinger's iconic status rests on his name itself, with all its bizarrely descriptive resonance and its filmic associations with evil desires for world dominance'. ${ }^{22}$ The other part of Goldfinger's iconic status rests on his forceful personality - a life-long Marxist with an unmistakable Hungarian accent and famously explosive temperament. When combined, it seems difficult for those depicting the tower to avoid what Michael Freeden has labelled the 'individualistic fallacy' which 'overstresses the function of a particular individual as the creator of a system' ${ }^{23}$ In this, it is commonplace for the trope of hero or villain to shape and dominate the discussion. Those inclined to read the story of Balfron Tower as a morality play of tyrannical hubris exaggerate both the intentions of Goldfinger's architecture and its lived actualities without evidence. The most common conception assumes Goldfinger's aim was to 
deliver utopia for its residents - an aim so unachievably high that anything less than the perfect society means failure. In this narrative arc, following the fall from utopia to dystopia, Goldfinger the hero is transformed into Goldfinger the villain. This gives rise to pathetic fallacy in which the architect is his building; Goldfinger, the supercilious or well-intentioned social engineer comes to look like his creation - a terrifying, flawed, tower of a man.

As I discovered further such representations, I came to realise how easy it is to be seduced by this dominating story; to conflate, without any available evidence to the contrary, these perceived experiences for lived ones and assume tenants have been clamouring to escape. Having dwelt in the speculative and the fictional, I too wish to escape, leaving behind the sofa strewn with popcorn kernels to enter the civilised academic spaces of the library and archive. Looking across the literature I gather on the tower, I identify a recent proliferation of accounts with a resurgence of interest in Balfron's quality, ideals, and social history.

The first trend is a renewed appreciation by historians and critics of the quality and originality of the tower. Andrew Higgott describes a new climate in which 'once disdained modern buildings such as the housing tower blocks by Goldfinger are now valued, not as curiosities, but as good architecture'. ${ }^{24}$ Kenneth Powell declares, 'Aesthetically, London's best high modern buildings are the two strange housing towers by that tough-minded disciple of Auguste Perret, the late Ernő Goldfinger'. ${ }^{25}$ Andrew Saint and Elain Harwood cheer these 'extraordinary' towers as 'isolated statements of French monumentalism and concrete technique in the unexpected settings of North Kensington and Poplar. ${ }^{26}$ Bridget Cherry recognises 'superior quality is at once apparent' when approaching Balfron: 'The twenty-six-storey block is immediately arresting, with its slender semidetached tower containing lift, services, and chunky oversailing boiler house' ${ }^{27}$ Alan Powers' lecture to the Royal Academy offered his audience an experiential account of the tower, in which he describes Balfron's architecture as neither alien nor imposed but well suited to its post-industrial landscape; it 'is a wonderful landmark, you really know where you are in East London when you see this, it does matter'. ${ }^{28}$ Similarly, on his 'walk around Poplar' a few years later, Owen Hatherley sees Balfron rising vertiginously, 'animating its attempt to protect residents from the din and ugliness of the Blackwall approach': its 'flats are large and simple, the bared concrete is beautiful, detailed with a craftsman's obsessiveness, the communal areas largely make sense, and the buildings have an impressive sense of order and controlled drama'. ${ }^{29}$ For these reasons Balfron is selected alongside Trellick Tower, its sister tower by Goldfinger in west London, in Hilary French's global survey of Key Urban Housing of the Twentieth Century. ${ }^{30}$

It is notable how many of these accounts reiterate the scholarship and emotional charge of two articles in 1983 by James Dunnett, a former employee of Goldfinger, which still comprise the most definitive texts on Balfron Tower to date. It is worth quoting at length from Dunnett's prologue to his first article, in which he argues it is time to take Goldfinger's work seriously:

The moral basis of Goldfinger's architecture as of all those who, like him, were closely involved with CIAM [the Congrès internationaux d'architecture moderne], was the detailed consideration of the environmental conditions conducive to human welfare - whether their analysis is now thought to have been complete or not. The high-rise housing schemes which he built for the GLC were a product of this consideration in every detail, designed to secure 'sun, space, and greenery' for their inhabitants. But in Goldfinger's hands the millennial utopian vision has acquired an air of menace, the ideal has been pushed to its very limits.

The sheer scale and drama of their architecture are exciting, but unnerving. Exciting because the control of form is so complete. The rhythms of the facades, founded on the mathematical control of proportion, are a statement of formal architectural values 
unequalled in this country, I would say, since Lutyens, a perfect resolution of horizontal and vertical elements. Raw concrete has rarely seemed so beautiful, its detailing handled with a knowledge beginning with Perret. The sequence of space and form is varied, picturesque, never repetitive: under a low evening sun one has the feeling of participation in an heroic landscape.

But it is unnerving not only because of scale -28 storeys at [Balfron], 30 at [Trellick] - but because of the choice of elements of a distinctly minatory character. It is as though Goldfinger, from among the Functionalist totems, had chosen as a source of inspiration the artefacts of war. The sheer concrete walls of the circulation towers are pierced only by slits; cascading down the facade like rain, they impart a delicate sense of terror ...

The intellectual power required to create a significant work of art can often seem frightening to others. It requires strength to be inspired by it and not run for cover. Goldfinger's is a demanding architecture, whose place is at the centre of intellectual life. ${ }^{31}$

In this, Dunnett uses oxymoron and metaphors as stark and dramatic as the architectural language of the building to advance an intellectual case intended not only to introduce us to Goldfinger's buildings but to introduce Goldfinger to the architectural canon. In his companion Architectural Review piece, Dunnett develops Goldfinger's adherence to the moral and aesthetic tenets of the Modern Movement, ${ }^{32}$ describing Balfron's design as 'a highly original synthesis'. In plan and section, the dual aspect flats served by an enclosed access gallery every third floor are a 'new' and 'satisfying' response to strict LCC briefs; in elevation, the rhythm of windows, slabs and crosswalls is 'of profound harmony', connected by access galleries that 'resemble a row of railway carriages' to the detached circulation tower set 'emphatically to one side' which Dunnett calls 'perhaps Goldfinger's most expressive invention'.

This work was cited heavily by English Heritage a decade later in a spot listing instigated by a resident to interrupt the Department of Transport's plans to replace Balfron's windows on the east façade because of the Highways Agency's road-widening of the Blackwall Tunnel approach. Their listing description provides a straightforward account of the arrangement, design and detailing of the tower; offering brief moments of praise for Balfron's 'unusually well thought-out' internal finishes, the 'distinctive profile that sets it apart from other tall blocks', and that, 'more importantly, it proved that such blocks could be well planned and beautifully finished, revealing Goldfinger as a master in the production of finely textured and long-lasting concrete masses'.33

The second trend across these academic accounts measures Balfron against currently held urban ideals today. Conservation specialist Martin O'Rourke's chapter in Preserving Post-War Heritage (2001) describes how the 'wave of optimism that characterised the post-war period of fifty years ago is difficult to appreciate in our more guarded and cynical times. It was an era when market forces and spending limits counted for less than social cohesion and better living standards for all'. ${ }^{34} \mathrm{He}$ advocates revisiting 'earlier modern attempts to reshape the city' which serve as 'inspirational beacons against which to test our own feeble attempts at a robust celebration of urbanism', citing 'Balfron Tower and its attendant building group' specifically as they 'constitute a major achievement of full-blooded modern architecture in the post-war period. It demonstrates that a social housing programme can be achieved with dramatic and high-quality architecture'. In his entry on the Brownfield Estate to a 2013 Design Museum exhibition, Lesser Known Architecture, Owen Hatherley agrees: 'These pieces of inner city architectural sculpture are fragments of a better, more egalitarian and more fearless kind of city than the ones we actually live in'. ${ }^{35}$ 
Perhaps because of this, the third trend to observe from this scholarship is a desire to piece together Balfron's social history and the social elements in its design. In his biography Ernö Goldfinger: The Life of an Architect, the philosopher Nigel Warburton quotes some of Balfron's original inhabitants and reappraises the 'sociological experiment' of 1968 in which Goldfinger and his wife Ursula moved to a flat at the top of the tower for its opening two months to diligently gather empirical knowledge. ${ }^{36}$ Warburton sees this as not only 'a public commitment to the virtues of high-rise living' but an opportunity 'to give a far more informed opinion of the benefits and problems when he had experienced them himself'. In her article for the Twentieth Century Society, historian Ruth Oldham mines the archives further and transcribes Ursula Goldfinger's diary notes from their stay, concluding an 'overall feeling one gets is of great support for this huge experimental building that her husband has built, and of absolute conviction that they should learn as much as they can from it'. $^{37}$

Before concluding on these three academic trends, I wish to turn to Goldfinger's exceptionally thorough archive, bequeathed to the RIBA upon his death, from which we can build a fuller picture of this 'sociological experiment'. ${ }^{38}$ Goldfinger requested privately to live in the block from February to April 1968 to document and assess his designs for high-rise living. Under Housing Committee Chairman Horace Cutler, the GLC accepted and elected to generate publicity around this. At Balfron Tower's completion in 1968, Goldfinger, not averse to a bit of publicity, informed the assembled group of national and international reporters that he wished to 'experience, at first-hand, the size of the rooms, the amenities provided, the time it takes to obtain a lift, the amount of wind whistling around the tower, and any problems which might arise from my designs so that I can correct them in the future'. ${ }^{39}$

Dozens of widely supportive articles quote Goldfinger's pitch for high-rise living enthusiastically: 'After six days of life high above the East End, Mr Goldfinger said: "I am enjoying this no end. I would love to live here"'. ${ }^{40} \mathrm{~A}$ few days later, he told a different reporter: "I have created here nine separate streets on nine different levels, all with their own rows of front doors. A community spirit is still possible even in these tall blocks, and any criticism that it isn't is just rubbish' ${ }^{41}$ In these articles, it is most revealing how little the building is mentioned. For the national and architectural press, the drama is instead in the Goldfingers' eight-week stay, treated with varying measures of amusement and admiration. After laughs have subsided, an earnest (but brief) debate emerges in the editorial pages of the architectural press. One article, entitled 'Out of Touch', muses on the nature of design and the relationship between built environment professionals and their users:

When Ernő Goldfinger occupied one of the Poplar flats for the purpose of 'sociological experiments', he was tacitly making an admission for the whole profession, by and large, that architects are out of touch with the community which they supposedly serve ... For the architect, as a member of a profession, enjoys economic and social privileges which lift him out of the mainstream of daily experience shared by the majority of the population - a disastrous situation for an artist. Professionally and socially, his life is hermetic ... How can he know what urbanism means to others, the majority, who are less favourably placed? How can he assess what life is like in a council flat served by the amenities of Wapping? How can he devise the best form of envelope to contain a way of life he does not understand? ${ }^{42}$

These press articles were collected fastidiously by Goldfinger, cut out and compiled into hardback notebooks available to view alongside private letters, notebooks and receipts. When he is not addressing reporters or conducting interviews for the BBC, Ernő Goldfinger attends an array of meetings including with the Tenants' Association and composes letters in response to sincere queries from members of the public who have contacted him following the news reports. Ursula Goldfinger fastidiously writes a diary which concentrates on the day to day use of the building: 
whether doors can be opened while pushing a pram, where to store things ${ }^{43}$ As well as productively dividing their time, the Goldfingers visit other flats together, recording encounters with those expressing delight at their new homes, as well as famously inviting tenants floor-by-floor to their penthouse for champagne parties where they mingled with notepads, collating opinions on the new homes in order to document and remedy design issues.

The records reveal a balance of praise and criticism through observation and conversation with other residents, establishing a strong relationship with residents (who make Goldfinger an honorary member of the Tenants' Association). The Goldfingers take the building and residents as evidence, conducting far more work than they have ever been given credit for in decades of accounts since, and demonstrating an empirical conviction to their endeavour. Based on his experiences and residents' feedback, Goldfinger wrote a report for the GLC dismissing any design issues and organisational difficulties as 'trivial' and concluding, 'On the whole, the general disposition of the buildings and the flats are acceptable. I am prepared to repeat the same design in future schemes'. ${ }^{44}$ The only time he strays from unadorned observation is when he sets out how to improve communal areas, 'For teenagers, rooms have been built in the service tower, away from the dwellings for: a) table tennis and/or billiards. b) jazz/pop room. c) hobby room, which can also be used for older people'. In this description, lifted from ideas in Ursula Goldfinger's diary, he picks out the spaces and social facilities provided for different age groups, explicitly aligning the form of the circulation tower and the podium in front to the communal activity he wishes to take place there. He places social considerations at the heart of his report:

The success of any scheme depends on the human factor - the relationship of people to each other and the frame to their daily life which the building provides. These particular buildings have the great advantage of having as tenants, families with deep roots in the immediate neighbourhood. In fact, most families have been re-housed from the adjoining streets. Of the 160 families, all except two, came from the Borough of Tower Hamlets.

The nine access corridors form so many East End pavements, on which the normal life of the neighbourhood continues. On 7 of these pavements there are 18 front doors while, on two levels - the ground floor and the 15th floor where there are maisonettes, there are 8 front doors. As far as possible, people from the same area were re-housed together - street by street. $^{45}$

Fifteen years later, Goldfinger was to bring up the human factor again in a brief interview. ${ }^{46}$ 'Of course', he replied when asked if he would design his two high-rise housing schemes in the same way again, and proceeded:

I would like to add a few words regarding the controversy of 'high-rise' buildings. The main trouble with 'high-rise' buildings in this country is the incompetence of managements:

1. Rehousing is done in a haphazard way. For instance, so called 'problem families' are dumped into unfamiliar surroundings, saddled with rents they cannot afford and are given practically no help to adjust

2. Maintenance is lamentable

3. Supervision is inadequate, incompetent and spiteful

4. Vandalism is practically encouraged by persons who are antagonistic to this sort of development

5. Tenants who are satisfied just let it be ... only those who are dissatisfied complain

6. The only complaint I came across - when living on the top floor of one of the buildings I designed and when I had my office at the foot of another for three years - was high rent. $^{47}$ 
These were to be Goldfinger's last words on Balfron Tower before his death four years later. He could not have imagined the resurgence of admiration and popularity of his towers. His irate and combative response testifies to the hostility with which the public regarded tower blocks. From this we can conclude two points.

The first concerns the importance of this body of scholarship. The vast majority of academic accounts addressing Balfron Tower appeared well after the listing decision in 1996, a time in which post-war high-rises were still very much out of favour. It was Dunnett's rigorous writings and sustained campaigning against popular opinion in the preceding decades that helped build the case for Balfron to be recognised by English Heritage. Other work since has validated this case and enriched Dunnett's work. Although academic recognition is by no means enough to sway political agendas, as exemplified by the fate of Alison and Peter Smithson's neighbouring Robin Hood Gardens (soon to be demolished), such work remains necessary as it is the foundation for any reevaluation to occur.

The second point concerns what is missing from these accounts. In decades of scholarship on Balfron Tower, the tower's residents - once the object and focus of Goldfinger's research on the tower have been overlooked. This omission is important. It does not make these accounts invalid, but it does make them incomplete. Scholars can justly claim the tower's distinction compared with the environmental and technical deficiencies that have afflicted other high-rise blocks, but without consulting successive generations of residents and engaging in discussions on Balfron's social life, persistent accusations of social suitability remain unaddressed. The perception of failure that Forty observed in public opinion of post-war architecture still haunts the tower. 
In 2013, halfway into my doctoral research on another east London housing estate, I was invited by Balfron Tower resident Felicity Davies to assist her in conducting an oral history project as her neighbours were leaving their homes to make way for refurbishment works. The refurbishment was part of an urban regeneration scheme that had begun in 2008 following stock transfer of the public housing estate from Tower Hamlets Borough Council to Poplar Housing and Regeneration Community Association (HARCA). The public focus and funding that accompanied preparations for the London 2012 Olympic Games was the catalyst for a regeneration vision for the borough which aimed to refurbish properties to Decent Homes standards, improve public spaces and add new affordable and private homes to create 'mixed-communities'. The plans detailed that approximately half of Balfron Tower's 146 dwellings would be sold to cross-subsidise the costly refurbishment of a Grade II listed building - which had degraded under a piecemeal approach to maintenance and repairs - to heritage standards. ${ }^{48}$ In 2010, however, the housing association informed the tenants of the 99 socially rented households in the tower (approximately half of which had registered their intention to stay) that it was 'possible but not probable' they would have a right of return to their homes following the works, citing 'the impact of the global financial downturn' and planning setbacks on the estate as the reasons for this uncertainty. ${ }^{49}$

We began our project with one-to-one interviews with residents using an oral history approach which opens with residents' first impressions of the tower and moves backwards and forwards from this point - where had they come from, what has happened since - to build a fuller picture of their relationship with the tower and to understand how profoundly these experiences are shaped by personal circumstance. Without fail, and without prompting, every interview referred back to the most famous resident 47 years ago: the architect himself. As our ambitions for the project developed, we became interested in how to re-stage this archival material on site, and brought in two other practitioners to collaborate. Together with oral historian Polly Rodgers and theatremaker Katharine Yates we conceived of a series of performative workshops, running in parallel with oral history interviews, re-enacting Goldfinger's own empirical methods during his 'sociological experiment' to share collective knowledge and experience. These workshops were informed and inspired by architectural historian and designer Jane Rendell's praxis of site-writing which 'enacts a new kind of art criticism, one which draws out its spatial qualities, aiming to put the sites of the critic's engagement with art first', and forged new connections with critical acts of re-enactment and engagement articulated in the work of performance theorists Rebecca Schneider, Heike Roms and Jen Harvie. ${ }^{50}$ We set up a poster at community events and bingo afternoons as an invitation for residents to meet their neighbours of 45 years ago.

We held workshops from September 2013 to March 2014, bringing us into conversation with 30 current and former residents of Balfron Tower. In our first, we hosted a champagne (actually discount cava) party in a neighbouring flat to the Goldfingers' on the top floor. I scripted the dialogue of actors playing Ernő and Ursula Goldfinger based on archival excerpts as well as other brief exchanges between the couple taken from oral history recordings. ${ }^{51}$ 'The Goldfingers' mingled throughout the evening, asking current residents the same questions about their everyday experience of the tower as they did 47 years ago, this time using audio recorders, not notepads, to record conversations in a dialogue between past and present. I had dressed each room of the twobed flat with archival material in situ: isometric sketches alongside press cuttings in the study; the many letters that Ernő had written to members of the public in the bedroom; and early photographs of the tower in the living room. The evening concluded with a set of film screenings and talks, including by James Dunnett who spoke about Docomomo, a conservation organisation that campaigns to raise awareness of the ideas and heritage of modern movement buildings, before a short excerpt of a BBC interview with Goldfinger during his stay in the tower. ${ }^{52}$ 
Our final workshop was held at the community centre at the foot of the tower in March 2014. We used the occasion to announce that the RIBA had approved our proposal to add our oral history interviews and any further documents residents wish to donate to their Goldfinger collection updating the records with 47 years' lived experience. The event re-enacted an occasion when Goldfinger attended an early Tenants Association meeting but, according to the archival record, contributed to the agenda only once, letting the residents share their thoughts openly and without interruption. The actor playing Goldfinger returned to recount his solitary line and it then opened to a group discussion between this community of outgoing residents who shared stories, opinions and feelings - particularly about the renovation and decant of the tower - as they negotiated the array of archival available around the room and on tables. Performing this construction of evidence made the subjectivity and staging of it explicit, allowing the archive, normally seen as having a fixed, authoritative character, to become alive to a more democratic chorus of voices.

Before I reflect on these oral history interviews and group workshops, I draw on residents' own words from them to identify how this building has framed residents' daily life and relationships to each other, categorised under six headings: ${ }^{53}$

Domestic experience - Common to residents is a feeling of intimidation upon first seeing Balfron, a building many would have never imagined inhabiting. This evokes negative associations, the 'kind of thing that you think of with inner-city tower blocks, but actually I found it to be a very different experience when I moved in'. 'When I knew I had to live here and I didn't have any choice, I wanted to run away, I didn't know anything about the tower. As soon as I moved in to the 21 st floor I just totally fell in love with it.' Instead of the powerful metaphors of war coined by Dunnett, the terms they invoke are more blunted and benign. 'I know architects think it's a marvellous thing but it's just another building to me.' 'It's a very trendy thing now, it's in fashion - what I like about it is being inside it.'

Interior layouts - Residents value the organisation and character of interior layouts, 'It's a lovely size in terms of the flat and I love the design.' 'I think the flats are wonderful places to live.' 'I can't think of anything I'd change in this flat.' The flats delighted first tenants as they were bigger and lighter than anything they were used to - 'it was like a palace' - and are still recognised as superior today: 'The flats are a great size, spacious - a luxury considering all the shoe boxes being built', 'It's a better design than anything now', offering 'the space to reflect and create'; 'to live in I don't think you can get much better'. However, many households on social rent in the tower, particularly Bengali Muslim families, have come to live in overcrowded conditions and would relish the opportunity to move to dwellings with more bedrooms.

Materials and detailing - Over decades of changing fashions, the interiors have been decorated to different tastes - overlaid brick cladding, thick pile carpets, patterned wallpaper - but many of the original design features remain and have lasted well, such as the full height timber windows, light switches set into door frames and pre-cast flower boxes that have encouraged wildlife - herons, peregrine falcons and 'squirrels [that] made it regularly to what I assume was the $23 \mathrm{rd}$ floor'. 'The planters are very useful. Since living here my flatmate and I have really got into tomato and marigold growing.' Residents admire the 'tremendous force attached to its material and its detailing' and the privacy that comes from 'very good soundproofing' and 'low noise from neighbouring flats' which enable some to feel 'enclosed and safe'. A mother described how it was a nice environment to raise her baby in Balfron 'because the flats were quiet' and 'really well designed'.

Quality of light and views - Most flats are double aspect except those on the south-face that are triple, and two-person flats featuring a sash window in the kitchen which opens onto the walkway 
facing east. Though residents complain that the full height partially glazed screens can be draughty, they cherish the quantity and quality of light they provide. 'Goldfinger designed with an awful lot of light. You live in the space in a different way. It affects your being. And that's critical to your entire existence.'

No matter how high residents live, with different proportions of city and sky, the view has become vital to a sense of spaciousness and belonging. It enhances the space in flats, giving the feeling 'like you have an outdoor space in your front room', that 'extend[s] outside the boundaries of our living room', but also of the estate, 'The view, not just outwards towards London skyline but inwards towards the Brownfield area. It's a very communal view and often there are kids playing in the sunken playground. It's been lovely these past few weeks of summer to come home and have a cup of tea on the balcony and just listen to the sound of activity below.'

The view is a source of personal contemplation and identity. 'The fact that it's in the sky is so important to it. I do feel a Londoner up here, ironically, you do see the cranes, you see the horizon as it changes, to see the Gherkin being built, to see the Shard, incredible'. 'Especially at night 'cos everything was lit up ... To me it was just like fairy lights. It was like fairy land, truly.' One resident who has lived with the view for twenty years fetched a small postcard print of German Romantic painter Caspar David Friedrich's Wanderer above the Sea of Fog during our interview: 'That's me looking out of the window, that's how I feel looking out of the window. That's my image of my life in the flat overlooking London.'

The view is also a backdrop and focus to the conduct of communal relationships, 'You don't really watch TV when you live somewhere with a nice view... every time you look out you can see different things'. Residents often contextualised their experience within the prevailing tendency in London to replace post-war social housing with privatised towers: 'We felt magnificent being up there. The view - we could see Battersea Power Station on a good day - you see everything from there. I think for social housing tenants to lose the view is such a terrible theft of experience.'

Communal experience - The first to move in remember the sociability concomitant with existing communal ties. 'I was here 40-odd years. I loved it. Everyone would help one another. You knew your next-door neighbour, you knew everyone. Even in the block, because as we moved the whole street moved into the block with us. So we still knew everyone and there was such a friendship and everything.' When asked about the communal experience today, residents acknowledge the consequences of long periods of poor social policy and unfailingly mention the two lifts that never appear to have been quick or reliable enough. They stand for the lack of sufficient funds for repair and improvement that has afflicted the building in spite of decades of demands from residents, leading to concrete spalling, corroded wiring conduits, leaking pipes and vermin infestations. The eventual installation of a door-entry system at Balfron curtailed instances of anti-social behaviour, but with the hobby rooms sealed off and long forgotten, residents feel the tower is missing spaces to facilitate communal interaction.

Yet the feeling of neighbourliness is not restricted to Balfron's early golden age. The nine distinct corridors which lead to three levels of flats offer 'more chance of meeting neighbours' and can be a 'great place to meet the neighbours and chat'. The intimacy these spaces provide is unexpected: 'it is the first time in my life I've got to know my neighbours', the 'friendliness isn't something I've experienced in other parts of London'. 'The ethnic community has changed ... I am proud that I am a member of a community that includes a staff sister, a child psychologist, a retired woodworker, Somali artists. People from all walks of life and cultural backgrounds. I am proud to be in Balfron Tower, and to be in Tower Hamlets. This is part of my identity'. 
Collective memory - The longest-serving residents remember meeting Goldfinger at his parties. 'He introduced himself and he asked our opinion of different things, what we thought of this and that. And he weighed it all in, so that when he built the other building, he done the adjustments, you know what I mean ... He noticed it all and he righted it.' Similar anecdotes have survived generations of new residents through continued conversations between neighbours, that have meant residents are well informed and inspired by its history. 'Trellick is more famous, but this place is more close to his heart in the fact that he lived here.' 'I tapped into the Goldfinger thing, I painted my whole flat gold ... I felt I could be really creative here ... [it] opened up a new world to me.'

In each of the oral history interviews we had conducted, residents lamented the lack of opportunities for communal interaction in the tower today. The workshops opened a social, discursive and imaginative space that brought different residents from different tenures together into one space to talk to one another. In this sense, our re-staging touched on the spirit of the original endeavour; a community was not just re-enacted but, if only temporarily, reconstituted. There was a considerable level of engagement with the material on display. Dressing a flat that is identical to residents' homes as an archive makes it estranging and uncanny, and it forced people to see their own flats differently and acted as a trigger for memories. Alongside the informal theatricality, it created a setting where people stepped outside their daily routine into a mode of critical reflection, to re-examine their estate, their flats and themselves.

Residents engaged enthusiastically with the performative premise and spoke freely in their own terms about their homes and the process of regeneration, to each other and to the actors, telling 'Goldfinger' of his inspiration to them or telling him off for the things that did not work. As the interviews and encounters progressed, I witnessed how knowledgeable the residents were about the process of refurbishment and the design and quality of their homes but, despite this, they bemoaned the lack of clarity and certainty about the regeneration and their own place within it. 
The processes of regeneration that had begun during my engagement with residents accelerated in the year leading up to the submission of refurbishment plans in September 2015. Housing association Poplar HARCA entered a joint venture partnership with property developers Londonewcastle and Telford Homes, recruiting architects Studio Egret West and designer Ab Rogers to develop proposals for external and internal physical alterations that would transform the character and tenure of Balfron Tower..$^{54}$ Below, I summarise our objections to these plans and actions we took beforehand on the grounds of accountable regeneration and informed heritage.

Accountable regeneration - The application's 130 documents contain no statement on the future tenure of Balfron Tower's 146 flats, an omission which indicates full privatisation and a resultant loss of 99 homes on social rent. This was in keeping with Poplar HARCA's policy after October 2010, as they continued to advise tenants that it was 'possible but not probable' they would have a right of return to their homes, offering instead assistance to relocate. ${ }^{55}$ In this time, tenants had sent moving letters of appeal to local newspapers and all levels of representative democracy, drafted online petitions and submitted Freedom of Information requests, but no further information or financial models were released to justify this decision.

It was during our project of interviews and workshops that I had come to realise this proposed privatisation had escaped media, cultural, intellectual and resident scrutiny, in part because of the difficulty of accessing and understanding material related to these complex and contested processes of change. This chimed with the experience of other campaign groups in London where information has been withheld or legislative definitions invoked ambiguously to cover a chasm between the promises and realities of social housing provision. ${ }^{56}$ As such, six months before the planning application was submitted, I produced an online archive in the hope that access to the full range of information on the history and future of the tower would enable the regeneration process to be subject to critical scrutiny and the force of informed public debate. Although it was late in the regeneration process, if there was still a potential opportunity to intervene and protect the provision of social housing in Balfron Tower as so strongly desired by current tenants and essential to its principles and purpose, then inaction, to me, seemed unethical.

I collaborated with designer Duarte Carrilho da Graça to make www.balfrontower.org, an openaccess website as a vehicle to communicate this volume of material which playfully reflects the aesthetic of Balfron Tower - an impossibly tall tower of 120 documents spanning five decades. ${ }^{57}$ These include adverts, architectural history accounts, archival records, art projects, blog articles, conservation management plans, council minutes, documentary films, feature films, financial viability reports, freedom of information requests, health reports, listing nominations, literary fiction, music videos, planning applications, press articles, promotional videos, public lectures, regeneration strategies and resident oral history testimonies. In their original form, these documents can be intimidating, difficult to access (because they are hidden behind archival protocols, journal subscription costs and labyrinthine planning portals) or difficult to understand because of bureaucratic, academic or legal language. When the user clicks on these documents they are whisked away to other pages, from which unabridged versions of the documents can be downloaded in full or selected key quotes and explanatory comments viewed. The user can also find a list of 13 questions, each of which, when clicked, provides a short answer and selects relevant documents from the timeline below, assembling quotes which act to provide a more detailed response. The website differs substantially from a typical academic output: rather than an authored article that takes time to polish and publish, it presents all relevant documents for the public to easily draw upon, opening up resources for scrutiny and providing the user the ability to construct their own narrative around the evidence in their own terms. 
The documents included made clear the statutory affordable housing targets and best practice guidelines on accountable regeneration that the planning application failed to meet.

Informed heritage - On the second point of our objection, the planning application provides a detailed account of the history of the tower, drawing extensively from the excellent Conservation Management Plan produced by Avanti Architects in 2007, which sets out its evidential, historical, architectural and communal heritage value. ${ }^{58}$ The Design and Access Statement describes Balfron Tower as having been 'designed with an exceptional attention to detail for a social housing project' and 'conceived with a spirit of 1960s optimism, designed to create contemporary housing for the masses and nurture a sense of community'. The importance of the tower's purpose as social housing for local communities is reinforced by the 'Hierarchy of significance'. The first point in this section addresses the 'social and political context', noting: 'The need for high quality housing to serve a modern post-war Britain informed Balfron's design. This is significant in historic and architectural terms. ${ }^{59}$ The 'Summary of significance' concludes, 'The iconic nature of the building, being a major selling point, needs to be conserved in its essence, according to the hierarchy of the above attributes. ${ }^{60}$

Before I turn to this 'major selling point', it is important to address the three ways in which the planning application diverges from Avanti's recommendations. Aesthetically, the plans set out the removal of the surviving original white-painted timber windows to be replaced with box-section brown anodised aluminium windows alongside stripping out existing flat plans - except for one of each type to be retained - to be replaced by 'open plan' layouts. Functionally, they transform these dwellings that were overwhelmingly allocated for social rent into properties for sale on the private market. Finally, in consultation approach, the plans state, 'As the building is Grade II Listed with design and refurbishment works needing careful consideration to comply with complex planning and heritage requirements, it was not felt appropriate to consult more widely on detailed design and heritage matters. ${ }^{61}$ A number of stakeholders were consulted but these included neither current and former residents of the tower nor the wider estate community. To exclude residents who know the building most intimately and assume they could not engage meaningfully in complex discussions is contemptible, especially considering Ernő Goldfinger's own methods of resident engagement.

This selective reading of Goldfinger's principles can be further witnessed in the design approach. The development partners state they intend to 'help realise the vision that Ernő Goldfinger had for it over half a century ago', 62 adding, 'We want to invoke Goldfinger's original optimistic spirit and sensitively refurbish Balfron Tower to be a shining exemplar of contemporary living again, this time for the 21st century. ${ }^{63}$ The inference from these statements is that refurbishment plans can deliver a vision Goldfinger himself was unable to achieve, reinforced by the intimation that the tower is no longer fit for purpose. They also position Goldfinger's 'optimistic spirit' as a cultural cache which, along with the 'iconic nature of the building', is invoked as a 'major selling point' to be marketed instead of principles and homes to preserve. ${ }^{64}$ The misconception at the heart of these design proposals is a fundamental distinction between heritage that pays tribute to these egalitarian principles and heritage that enacts these principles.

In anticipation of this, I assisted James Dunnett in writing a Grade II* listing upgrade nomination in August 2014, over a year before the planning application was submitted. Our reasons were threefold; firstly, we believed all of Goldfinger's work on the Brownfield Estate - including specifically the spaces between the buildings which can be vulnerable to development pressures should be protected to recognise their exceptional architectural quality. Secondly, an enhanced level of listing would ensure Historic England's active involvement in assessing any application for listed building consent, and thirdly, the current listing descriptions should be elaborated on to reflect the social elements in the design. 
On this final point, the principles and grounds of our argument explicitly emphasised the importance of Balfron's social context, integral to the vision and function of the building and an intrinsic part of its architectural heritage. I had been inspired by campaigners fighting against the conversion of Berthold Lubetkin's Finsbury Health Centre, and by architectural writer and local councillor Emma Dent Coad, who represents the residents of the Cheltenham Estate comprising Goldfinger's Trellick Tower. Dent Coad had issued a rallying cry on preserving such buildings: 'we must get our hands dirty to engage politically, comprehensively and at the right time... If we determine that social purpose must also be conserved, we must look beyond physical conservation and commit to keeping these homes in the social sector'. ${ }^{65}$ Dunnett produced a rigorous history of the tower, noting: 'It would be regrettable if the Tower were to be converted into just more housing units on the private open market - as is in prospect: its architectural "message" would be compromised. ${ }^{66}$ । accompanied this with a supplementary document devoted to residents' experiences, challenging the dominant discourse that Balfron Tower has failed, identifying the aspects of the building that residents cherished, and to testify to its ongoing social function. ${ }^{67}$ And Owen Hatherley wrote a statement in support, concluding:

The listing of buildings should always be careful not to be just a matter of listing a few lone 'icons' to be preserved as toys, and be careful not to list buildings as shells that can be filled with anything, particularly when their purpose is still very much needed. On this basis I support the listing of the Brownfield Estate as a whole as a coherent, well made and complete example of public housing well above the current standard of private housing and which must stay as public housing, in an area that desperately needs it. On both architectural and social grounds, this is a place which needs preserving. ${ }^{68}$

By the time Tower Hamlets Development Committee met to consider the planning application in December 2015, the archive website had been viewed by residents, community groups and the wider public 12,000 times. Alongside this, I had drafted a fully referenced statement of objection, which was used as the basis of a petition coordinated by tireless resident and campaign groups Balfron Social Club and Tower Hamlets Renters - amassing the support of 2,800 people in its first week. ${ }^{69}$ Our objections were further articulated by an Architects' Journal article by residents; ${ }^{70}$ enriched by objections on aesthetic grounds by DoCoMoMo-UK and the Twentieth Century Society ${ }^{71}$ and amplified by a speech drawing explicitly on our research by Baron Cashman in a debate to the House of Lords on the regeneration of east London. ${ }^{72}$ This was consolidated by a decision from the other side of the Houses of Parliament. While Balfron Tower Developments had been preparing this planning application, Historic England were completing their year-long assessment of our listing upgrade nomination. One month after the planning application was submitted, the Culture Minister ratified this upgrade to Grade $1{ }^{*} .^{73}$ The new listing statement recognised the social ideals and purpose of the tower as a key component of its heritage:, 'Balfron Tower was designed as a social entity to re-house a community, according with Goldfinger's socialist thinking'. And among its 'principal reasons' for listing, Historic England noted 'Architectural interest: a manifestation of the architect's rigorous approach to design and of his socialist architectural principles' and 'Social and historic interest: designed to re-house a local community'. ${ }^{74}$

I had been driven by the conviction that if all the archival, academic and empirical evidence was presented alongside relevant policy, guidance and precedent, councillors could not help but demand accountability for their socially housed constituents and demand a more informed approach to heritage. Devastatingly, and unanimously, the Development Committee vote to refurbish, and with it any opportunity to prevent the privatisation, passed. ${ }^{75}$ As we left the council chamber I had in my mind the words of a Municipal Dreams blogpost whose author had foreseen this outcome: 
Defenders of Poplar HARCA would argue they are doing their best to work the system - a sell-off of prime real estate here, some replacement social housing there. The rules require that we sell off homes in the social rented sector to maintain the ones we have. The same rules imply that some homes are too good for ordinary people. And, in practice, those rules break up communities and disperse too many tenants far from their original homes and neighbourhoods ... [Balfron's] sell-off is a loss of housing for those who need it most. For the rest of us, it's a loss of common purpose and decency. ${ }^{76}$ 


\section{'An exemplar': Concluding remarks}

This sustained engagement with residents reaffirmed the duty we have to put our work at the service of those whose lives we seek to improve. Bringing archival, bureaucratic and academic material into their homes opened access for residents to speak to these debates, and to one another, as peers. Residents' fuller historical accounts challenge the dominant discourse that Balfron Tower has failed. Their testimonies neither reinforce stereotypical images of high-rise housing estates nor hide their faults; instead they display the liveliness, diversity and vibrancy of such estate communities. In doing so, they advance an argument for the continued and urgent need for public housing as these communities and the qualities they bring to London are diluted or dispersed. By collaborating to produce the online archive, listing nomination and campaign we transformed what had been framed and suppressed for five years as a marginal and private issue into a matter of legislative and public concern which held Balfron Tower as a beacon for public housing, against which current regeneration policy was found wanting.

In the planning application, the development partners define Balfron Tower as 'an exemplar of postwar social housing'. They introduce their plans to 'sensitively refurbish [it] to be a shining exemplar of contemporary living again', and declare their aim to 'deliver an exemplar project and provide a legacy that all will be proud of'. ${ }^{77}$ Rather than 'an exemplar', repeated 18 times in total, the proposals exemplify the current practice of heritage which strips social housing estates of their egalitarian principles and purpose, exemplify contemporary developments that segregate and stratify local communities, and exemplify an unethical dispossession of social housing in London that constitutes a major contributing factor to the city's housing crisis.

It is perhaps too late for the housing association to reconsider its approach and deliver a truly exemplary project at Balfron Tower, but it is certainly not too late for other developments in London. These could set the benchmark for regeneration and heritage schemes by addressing: accountable regeneration - opening full access to information in order to justify decisions; affordable housing - retaining a proportion of social housing genuinely affordable to local communities; inclusive consultation - developing proposals together with residents in which everyone is able to fully participate; and informed heritage - identifying and preserving shared historical and communal values. 
${ }^{1}$ Peter Golds, 'Towers of London', Conservative Home, 2013:

www.conservativehome.com/localgovernment/2013/11/towers-of-london.html (accessed 17 Jan. 2016); LBC Radio, 'Balfron Tower: Eyesore or Landmark?', 14 Aug. 2015: www.lbc.co.uk/balfron-tower-eyesore-orlandmark-114623 (accessed 17 Jan. 2016).

${ }^{2}$ Adrian Forty, 'Being or Nothingness: Private Experience and Public Architecture in Post-War Britain', Architectural History, vol.38, 1995, pp.25-35.

${ }^{3}$ Ibid., p.28.

${ }^{4}$ Two decades later, a growing body of scholarship is dedicated to this actual question of failure, as it is so regularly invoked as grounds for demolition of post-war housing estates, in turn severing kinship networks as families and communities are dispersed.

${ }^{5} 28$ Days Later, dir. Danny Boyle (2002).

${ }^{6}$ Blitz, dir. Elliott Lester (2011).

${ }^{7}$ Shopping, dir. Paul WS Anderson (1994).

${ }^{8}$ Ibid.

${ }^{9}$ Ben Campkin, Remaking London, IB Taurus, London 2013, p.100.

${ }^{10}$ Gareth Roberts, 'National Trust adopts "Britain's ugliest building" as star attraction for two-week architecture tour', Mirror, 24 Sept. 2014.

${ }^{11}$ Eddy Frankel, 'What's the storey?', Time Out, 26 May 2015.

${ }^{12}$ Chris Pleasance, 'Step back in time with the original Goldfinger: Flat in the 60s towerblock designed by architect who gave Bond baddy his name is lovingly recreated', Daily Mail, 27 Sept. 2014.

${ }^{13}$ Melanie Wright, 'Personal finance? We can teach you a thing or two', Sunday Times, 5 Oct. 2014; LBC Radio 2015; Roberts, 'National Trust'; Louise Jury, 'National Trust opens Sixties flat in 'Britain's ugliest building", Evening Standard 26 Sept. 2014.

${ }^{14}$ Anon., 'Tower block tours give "Brutalism" a closer look', Agence France Presse, 30 Sept. 2014.

${ }^{15}$ Simon Jenkins, 'Betjeman and Pevsner taught us how to see', Times, 17 March 2000.

${ }^{16}$ Reyner Banham, The New Brutalism: Ethic or Aesthetic?, Reinhold, New York 1966.

${ }^{17}$ Ike ljeh, 'A look back at 1963 - the year of the Beatles, sexual politics and tower blocks', Building, 2 May 2013.

${ }^{18}$ Paul Waugh, 'Watchdog study to expose asbestos-ridden flats', Evening Standard, 30 May 1997; Tom Parry, '13.5m Live in a Britain Where Parents Face a Choice: Feed Their Children or Keep Them Warm at Night', Mirror, 19 Sept. 2011; Hannah Ellis-Petersen, 'Decaying east London tower block to house 12-hour Macbeth production', Guardian, 19 June 2014.

${ }^{19}$ Jess Bowie, 'Painting exhibition of Goldfinger's other modernist tower', Architects' Journal, 16 Jan. 2009; Parry 2011.

${ }^{20}$ Charlotte Bell and Katie Beswick, 'Authenticity and Representation: Council Estate Plays at the Royal Court', New Theatre Quarterly, vol.30, no.2, May 2014, pp.120-35 (p.132).

${ }^{21}$ Nigel Warburton, Ernö Goldfinger: The Life of an Architect, Routledge, London 2005.

${ }^{22}$ Neil Cameron, 'Understanding Ernő', Architects' Journal, vol.220, no.2, 2004, p.44.

${ }^{23}$ Michael Freeden, 'The Stranger at the Feast: Ideology and Public Policy in 20th Century Britain', 20th Century British History, vol.1, no.1, 1990, pp.9-34. Cited in Elizabeth Darling, Re-Forming Britain: Narratives of Modernity before Reconstruction, Routledge, London 2007, p.5.

${ }^{24}$ Andrew Higgott, Mediating Modernism: Architectural Cultures in Britain, Routledge, London 2007, p.15.

${ }^{25}$ Kenneth Powell, World Cities: London, The University of Michigan, Michigan 1993, p.15. 
${ }^{26}$ Elain Harwood and Andrew Saint, London, HMSO Books, London 1991, pp.107-9.

${ }^{27}$ Bridget Cherry, Charles O'Brien and Nikolaus Pevsner, The Buildings of England, London 5: East, Yale University Press, London and New Haven 2005, pp.656-7.

${ }^{28}$ Alan Powers, 'Ernő Goldfinger' in Maxwell Hutchinson (ed.), The Architects Who Made London, The Royal Academy, London 2009.

${ }^{29}$ Owen Hatherley, A New Kind of Bleak: Journeys Through Urban Britain, Verso, London 2012, p.29.

${ }^{30}$ Hilary French, Key Urban Housing of the Twentieth Century: Plans Sections and Elevations, Laurence King, London 2008, pp.138-9.

31 James Dunnett and Gavin Stamp, Ernő Goldfinger: Works 1, Architectural Association, London 1983, p.7.

32 James Dunnett, 'Ernő Goldfinger: The Architect as Constructor', Architectural Review, vol.173, April 1983, pp.42-8.

${ }^{33}$ English Heritage, 'List entry summary: Balfron Tower, St Leonards Road', 1996:

www.balfrontower.org/document/16/list-entry-summary-balfron-tower-st-leonards-road (accessed 17 Jan. 2016).

${ }^{34}$ Martin O'Rourke, 'The Lansbury Estate, Keeling House and Balfron Tower: Conservation issues and the architecture of social intent' in Susan MacDonald (ed.), Preserving post-war heritage: The care and conservation of mid-twentieth century architecture, Donhead Publishing, Shaftesbury 2001, pp.169-76.

35 Owen Hatherley, 'Lesser Known Architecture', Design Museum, 2013.

${ }^{36}$ Warburton 2005, pp.157-62.

${ }^{37}$ Ruth Oldham, 'Ursula Goldfinger's Balfron Tower Diary and Notes', C20 Society, Autumn 2010, pp.22-3.

${ }^{38}$ See Archive material held at the RIBA British Architectural Library, Drawings and Archives Collections: Gol/Er/170/6-7; Gol/Er/171/1-12; Gol/Er/391/1; PB667/1; PB688/1-2; PB752/1; PB1086/2; PB1087/1; PB1090/6; PB2062/2.

${ }^{39}$ Ernő Goldfinger, quoted in Anon, 'Finding the high life in Poplar', Guardian, 14 Feb. 1968.

${ }^{40}$ Ernő Goldfinger, quoted in 'High living sampled by architect', Daily Telegraph, 23 Feb. 1968.

${ }^{41}$ Ernő Goldfinger, quoted in 'East End's tallest block of flats make "ideal homes"', East London Advertiser, 1 March 1968.

42 Editorial, 'Out of touch', The Architect \& Building News, 6 March 1968, p.353.

${ }^{43}$ RIBA BAL, GolEr 391/1, Ursula Goldfinger, 'General Report, Balfron Tower', 1968.

${ }^{44}$ RIBA BAL, GolEr 391/1, Ernő Goldfinger, 'Rowlett Street Housing Press Report', 13 May 1968.

${ }^{45}$ Ibid.

${ }^{46}$ Dunnett 1983.

47 Ibid.

48 London Borough of Tower Hamlets, 'Formal consultation on the proposed regeneration and transfer of the East India Area to Poplar HARCA', 2006, p.23.

49 'Consultation undertaken has shown that approximately half of the residents in the two blocks [Balfron Tower and Carradale House] said that they would prefer to move out', which suggests approximately half would prefer to stay put - around 117 households between the two buildings. London Borough of Tower Hamlets 2006, p.23. See also London Borough of Tower Hamlets, 'Estate Monitoring Freedom of Information request', 2010, p.2.

50 Jane Rendell, Site-Writing: The Architecture of Art Criticism, I.B. Tauris, London 2010; Heike Roms and Rebecca Edwards, 'Oral History as Site-Specific Practice: Locating the History of Performance Art in Wales', in Shelley Trower ed., Place, Writing, and Voice in Oral History, Palgrave Macmillan, London 2011, pp. 171-192; Rebecca Schneider, Performing Remains: Art and War in Times of Theatrical Reenactment, Routledge, London 2011; Jen Harvie, Fair Play: Art, Performance and Neoliberalism, Palgrave Macmillan, London 2013. I have 
written elsewhere about the methodological approach to these re-enactments. See David Roberts, 'Housing Acts' in Andrew Filmer and Juliet Rufford (eds.), Performing Architectures: Contemporary Projects, Practices and Pedagogies, Bloomsbury Methuen Drama, London 2017.

${ }^{51}$ See Passionate Rationalism: Recollections of Ernö Goldfinger, British Library and National Trust, London 2004.

52 Docomomo-UK is the UK branch of the international UNESCO-recognised non-profit organisation for Documentation and Conservation of Buildings, Sites and Neighbourhoods of the Modern Movement.

53 I have anonymised excerpts from residents' testimonies for the protection of freedom of expression.

54 London Borough of Tower Hamlets, Application PA/15/02554, 2015.

55 David Roberts, Balfron Tower: a building archive, 2015: www.balfrontower.org (accessed 17 Jan. 2016).

${ }^{56}$ Oliver Wainwright, 'Revealed: how developers exploit flawed planning system to minimize affordable housing', Guardian, 25 June 2015.

${ }^{57}$ Roberts 2015.

${ }^{58}$ Avanti Architects, 'Conservation Management Plan: The Brownfield Estate, Poplar', 2007.

${ }^{59}$ Richard Coleman, 'Balfron Tower: Heritage Significance Report', 2015, p.44.

60 Ibid., p.45.

${ }^{61}$ Nudge Factory, 'Balfron Tower: Statement of Community Involvement', 2015, pp.4-5.

62 Londonewcastle, 'Joint Venture announced to give iconic Balfron Tower a new lease of life', 2014.

${ }^{63}$ Studio Egret West, 'Balfron Tower: Design and Access Statement', 2015, p.18.

${ }^{64}$ There is a vital, parallel story of the strategic use of cultural activity at Balfron Tower to maximise financial value which writer Feargus O'Sullivan has labelled 'artwashing'. The implications of this has been critically and urgently exposed by artist and former resident Rab Harling and campaign group Balfron Social Club. Feargus O'Sullivan, 'The Pernicious Realities of "Artwashing"', The Atlantic Cities, 2014; Rab Harling, rabharling.com; Balfron Social Club, 50percentbalfron.tumblr.com (accessed 17 Jan. 2016).

65 Emma Dent Coad, 'Conserving Living Buildings', in Ben Campkin, David Roberts and Rebecca Ross (eds.), Urban Pamphleteer 2: Regeneration Realities, Belmont Press, Northampton 2013, pp.5-6.

${ }^{66}$ James Dunnett, 'Brownfield Estate: Grade 2* Listing Nomination Reasons Text', 2014, p.1.

${ }^{67}$ David Roberts, 'Residents' Experiences of Balfron Tower', 2014.

68 Owen Hatherley, 'Listing Upgrade Supporting Statement', 2014, p.1.

69 David Roberts, 'Report in objection to proposal PA/15/02554', 2015; Balfron Social Club, 50percentbalfron.tumblr.com; Tower Hamlets Renters, towerhamletsrenters.wordpress.com (accessed 17 Jan. 2016).

${ }^{70}$ Vanessa Crawford, 'Balfron residents: "Privatising the tower will segregate the community"', Architects' Journal, 3 Nov. 2015.

${ }^{71}$ Laura Mark, 'C20 Society: 'Loss of Goldfinger features at Balfron not justified", Architects' Journal, 14 Oct. 2015.

72 Baron Cashman, 'Olympics 2012: Regeneration Legacy', Lords Hansard, 5 Nov. 2015.

${ }^{73}$ Historic England, 'Balfron Tower: List Entry Summary', 2015: historicengland.org.uk/listing/the-list/listentry/1334931 (accessed 17 Jan. 2016).

74 Ibid.

75 This was aided by the fact that Historic England had issued a further statement endorsing the refurbishment plans. For a robust and critical stance see, James Dunnett, 'Historic England is failing in its mission', Architects' Journal, 6 Jan. 2015. 
76 'Balfron Tower, Poplar: '"they all said the flats were lovely"', Municipal Dreams, 2014:

municipaldreams.wordpress.com/2014/10/21/balfron-tower-poplar-2/ (accessed 17 Jan. 2016).

${ }^{77}$ Studio Egret West 2015, p.18. 